\title{
Antimicrobial Effects of Boric Acid against Periodontal Pathogens
}

\author{
Borik Asitin Periodontal Patojenler Üzerine Olan Antimikrobiyal Etkileri \\ Kübra Aral ${ }^{1 *}$, Özge Çelik Güler², Paul R Cooper ${ }^{3}$, Satvir Shoker ${ }^{4}$, Sarah A Kuehne ${ }^{5}$, Michael R \\ Milward $^{6}$
}

${ }^{1}$ University of Birmingham, School of Dentistry, Department of Oral Biology, UK. Orcid: 0000-0003-4798-4548

2University of Birmingham, School of Dentistry, Department of Oral Biology, UK. Orcid: 0000-0003-3276-2408

${ }^{3}$ University of Birmingham, School of Dentistry, Oral Biology, UK.

${ }^{4}$ University of Birmingham, School of Dentistry, Oral Biology, UK

Orcid: 0000-0003-1305-7287

${ }^{5}$ University of Birmingham School of Dentistry and Institute of Microbiology and Infection, Oral Microbiology, UK

Orcid: 0000-0001-6790-8433

${ }^{6}$ University of Birmingham, School of Dentistry, Department of Periodontology, UK Orcid: 0000-0002-9089-687X

Atıf/Citation: Aral, K., Güler, Çelik, Ö., Cooper, P. R., Shoker, S., Kuehne, S.A. \& Milward, M.R. (2020). Antimicrobial Effects of Boric Acid Against Periodontal Pathogens. Ege Üniversitesi Diş Hekimliği Fakültesi Dergisi, 41(1), $20-25$.

\begin{abstract}
Purpose: Boron is a bioactive trace element found in humans and essential for the growth and maintenance of bone and also has reported anti-inflammatory and antimicrobial activity. Boric acid is a well-characterised boron-containing compound which reportedly can reduce periodontal inflammation. Thus, the aim of the current study was to evaluate the possible bactericidal and/or bacteriostatic effects of boric acid on the periodontal pathogens: Fusobacterium nucleatum and Porphyromonas gingivalis.
\end{abstract}

Materials and Methods: Minimum inhibitory concentration (MIC) of boric acid on F. nucleatum (ATCC 10953) and P. gingivalis (ATCC 33277) were determined by the broth microdilution method. Overnight cultures were diluted to the following starting concentrations: $5 \times 10^{5} \mathrm{cfu} / \mathrm{ml}$ for F. nucleatum and $5 \times 10^{6} \mathrm{cfu} / \mathrm{ml}$ for P. gingivalis. After incubation for $48 \mathrm{~h}$ at $37^{\circ} \mathrm{C}$ in an anaerobic cabinet the absorbance of the cultures was measured. The minimum bactericidal concentration (MBC) was determined by plating an aliquot of the cell suspensions on agar plates, and bacteria were counted after incubation at $37^{\circ} \mathrm{C}$ for $48 \mathrm{~h}$ under anaerobic conditions.

Results: Boric acid was able to inhibit the growth of F. nucleatum at a concentration of $780 \mathrm{nM}$ and P. gingivalis at a concentration of $1.56 \mu \mathrm{M}$. The $\mathrm{MBC}$ of boric acid was $19 \mathrm{mM}$ for F. nucleatum however using tested concentrations (75 mM-1nm) were insufficient to provide an $M B C$ for $P$. gingivalis.

Conclusion: Boric acid may be a possible candidate for providing local antimicrobial actions on periodontal pathogens and therefore may have potential as a therapeutic intervention in the management of periodontal disease.

Keywords: Boric acid, Fusobacterium nucleatum, Porphyromonas gingivalis, periodontal disease, Antimicrobial Drug Resistance, boron

\section{Öz}

Amaç: Bor, kemiğin gelişimi ve idamesi için gerekli olup antiinflamatuar ve antimikrobiyal özelliklere sahip biyoaktif eser bir elementtir. Borik asit sıklıkla kullanılan bir bor bileşiği olup periodontal inflamasyonu azaltabildiği gösterilmiştir. Bu çalışmanın amacı borik asitin periodontal patojenlerden Fusobacterium nucleatum and Porphyromonas gingivalis üzerine olabilecek mevcut bakterisidal ve/veya bakteriostatik etkilerini incelemektir.

Gereç ve yöntem: Borik asitin F. nucleatum (ATCC 10953) ve P. gingivalis (ATCC 33277) için minimum inhibitör konsantrasyonu (MiK) sıvı besiyeri mikrodülisyon metodu yardımıyla saptanmıştır. Gecelik kültürler F. nucleatum için $5 \times 10^{5} \mathrm{cfu} / \mathrm{ml}$ ve P. gingivalis için $5 \times 10^{6} \mathrm{cfu} / \mathrm{ml}$ konsantrasyonuna seyreltilmiştir. Aaerobik bir kabinde $37^{\circ} \mathrm{C}$ de 48 saat inkübasyon sonrasında kültürlerin absorbansı ölçülmüştür. Minimum bakterisidal konsantrasyon (MBK) bakteri süspansiyonundan alınan alikotların agarlar üzerinde $37^{\circ} \mathrm{C}$ de 48 saat boyunca anaerobik koşullarda bekletilmesinden sonra bakterilerin sayılması sonucu elde edilmiştir.

Bulgular: Borik asit F. nucleatum'un üremesini $780 \mathrm{~nm}$ da P. gingivalis'in üremesini ise $1.56 \mu \mathrm{M}$ konsantrasyonda durdurabilmiștir. Borik asitin F. nucleatum için MBK değeri 18.75 nM olarak saptanmış fakat denenen konsantrasyonlar (75 mM-1nm) P.gingivalis için MBK değeri verememiştir.

Sonuç: Borik asit periodontal patojenlere karşı lokal antimikrobial etki gösteren bir aday olabileceğinden dolayı periodontal hastalığın tedavisinde terapötik potansiyeli olabilir.

Anahtar kelimeler: Borik asit, Fusobacterium nucleatum, Porphyromonas gingivalis, periodontal hastalık, Antimikrobiyal Ilaç Direnci, bor. 



\section{INTRODUCTION}

Periodontal disease is a chronic inflammatory condition associated with multispecies biofilms causing destruction of periodontal tissues around teeth ${ }^{1 .}$ The periodontal pathogens Porphyromonas gingivalis ( $P$. gingivalis), and Fusobacterium nucleatum (F. nucleatum) present in the dental plaque biofilm are associated with disease progression. P. gingivalis is a non- motile, Gram negative, obligate anaerobic bacilli found in the subgingival sulcus of the oral cavity and the numbers of this bacterium found in the periodontal pocket has been positively correlated with periodontitis while levels are lower or almost non-detectable in cases of subgingival health ${ }^{2}$. F. nucleatum is a Gram negative anaerobic bacterium that is considered as an intermediate colonizer bridging the attachment of commensals that colonize the tooth and epithelial surface with pathogenic species ${ }^{3}$.

During the treatment of periodontal disease reduction of total periodontal pathogen load by subgingival and supragingival mechanical debridement is one of the key treatment steps. However some subgingival pathogens may reside in inaccessible areas and, mechanical therapies alone may fail to eliminate these bacteria present in the host tissues. Therefore, the use of antimicrobial therapy, such as application of topical antibiotics and topical antiseptics, adjunct with mechanical debridement has been proposed ${ }^{4}$. Notably the use of systemic antibiotics could lead to an increase in bacterial resistance and superinfections ${ }^{5}$. Re-infection from non-treated sites may also be a problem in the case of use of topical antibiotics ${ }^{6}$. Indeed the application of antimicrobials such as chlorhexidine (CHX) has been reported to have limited success because of its potential cytotoxicity ${ }^{7}$ and limited antimicrobial activity within biofilms ${ }^{8}$.

Boron is a trace element which is essential for the growth and maintenance of bone ${ }^{9}$, and it has the reported ability to improve wound and alveolar bone healing ${ }^{10}$. Boron-containing compounds (BCCs) which possess unique and attractive biological properties including antibacterial, antifungal, antiparasitic, antiviral, and anti-inflammatory activities, have received increasing attention recently ${ }^{11}$. Boric acid is one of the most wellcharacterised BCCs reported in the literature and has been found to reduce alveolar bone loss ${ }^{12,13}$ and periodontal clinical parameters ${ }^{14,15}$. A mouthwash form of boric acid was also found superior compared with CHX in chronic periodontitis patients in improving periodontal clinical parameters ${ }^{16}$. However to date no study has evaluated its possible bacteriostatic or bactericidal effects on periodontal pathogens $P$. gingivalis and $F$. nucleatum. Thus the aim of the current study was to investigate the minimum inhibitory concentration (MIC) that shows the inhibitor dose of bacterial growth and minimum bactericidal concentration (MBC) that reflects the nonviability of bacteria treated with boric acid on $P$. gingivalis and F. nucleatum.

\section{MATERIALS AND METHODS}

\section{Preparation of Boric Acid}

Boric Acid (Sigma-Aldrich, MO, USA) was dissolved in $\mathrm{ddH}_{2} \mathrm{O}{ }^{17}$. The solutions were sterilized by filter sterilisation using a $0.22 \mu \mathrm{m}$ syringe-filter unit (Merck, Darmstadt, Germany). Concentrations were prepared ranging between $75 \mathrm{mM}$ to $1 \mathrm{~nm}$.

\section{Bacterial Culture}

F. nucleatum (ATCC 10953) was inoculated anaerobically (Don Whitley DG 250 anaerobic workstation, Don Whitley Scientific, West Yorkshire, England; atmosphere: 80\% nitrogen, 10\% carbon dioxide and $10 \%$ hydrogen) at $37{ }^{\circ} \mathrm{C}$ onto blood agar plates (Oxoid, Hampshire, UK) from a frozen stock for 48 hours ${ }^{18}$.

P. gingivalis ATCC 33277 was also grown onto blood agar plates anaerobically (Don Whitley DG 250 anaerobic workstation, Don Whitley Scientific, West Yorkshire, England; atmosphere: $80 \%$ nitrogen, 10\% carbon dioxide and 10\% hydrogen) (Oxoid, Basingstoke, UK) at $37{ }^{\circ} \mathrm{C}$ for 72 hours ${ }^{18}$.

A single representative colony from each bacteria was inoculated into $10 \mathrm{ml}$ broth for each bacterial species and cultured for 24 hours. Subsequently, $1 \mathrm{ml}$ of bacterial culture was taken from the overnight culture and read in the spectrophotometer at 600nm (Jenway 7315, Cole Parmer, Staffordshire, UK). The bacterial cell concentrations were determined with $\mathrm{OD}$ value according to the growth curve generated ${ }^{18}$.

\section{Minimal Inhibitory Concentration (MIC)}

MICs of the compound were determined by broth microdilution method previously described ${ }^{19}, 20$. Serial dilutions of the boric acid were performed in Schaedler Anaerobe Broth ${ }^{21}$ (at a volume of $100 \mu \mathrm{L}$ per well in 96well microtitre plates (Thermo-Fischer Scientific, MA, USA). Each well of a microwell plate was inoculated 
with $10 \mu \mathrm{L}$ of the diluted bacterial culture at a final concentration of $5 \times 10^{5} \mathrm{cfu} / \mathrm{ml}$ for F. nucleatum ${ }^{19}$ and $5 \times 10^{6} \mathrm{cfu} / \mathrm{ml}$ for $P$. gingivalis ${ }^{19}$. After incubation for $24 \mathrm{~h}$ and $48 \mathrm{~h}$ at $37^{\circ} \mathrm{C}$ the absorbance of the plates was measured at $600 \mathrm{~nm}$ using a microplate reader (ELX800 absorbance microplate reader, Bio-Tek; USA). The MIC was defined as the lowest concentration of the compounds tested that completely inhibited growth or produced at least $90 \%$ reduction in absorbance compared with the negative (compound-free) control. The MIC value represented the average of at least 3 independent experiments ${ }^{19}$.

\section{Minimal Bactericidal Concentrations (MBC)}

MBC was determined by plating an aliquot of cell cultures $(10 \mu \mathrm{L})$ from four wells above the MIC on agar plates ${ }^{22}$, and bacteria were counted after incubation at $37^{\circ} \mathrm{C}$ for $48 \mathrm{~h}$. The MBC was defined as the lowest concentration of the compound at which more than $99.9 \%$ of the bacteria were killed compared with a non-treated control ${ }^{19}$.

\section{RESULTS}

Boric acid concentrations of $75 \mathrm{mM}$ to $1 \mathrm{~nm}$ were tested against $P$. gingivalis and F. nucleatum for MIC determination (Table 1). The MIC of Boric acid was determined as $780 \mathrm{nM}$ for F. nucleatum. However, a higher dose $1.56 \mu \mathrm{M}$ of Boric acid was found to be required for $P$.gingivalis (Table 1$)$.

After determination of the MIC, aliquots were transferred onto agar plates for determination of the MBC.

The MBC value of Boric acid was determined to be considerable higher compared with the MIC value for $F$. nucleatum being $19 \mathrm{mM}$. No MBC could be determined for $P$. gingivalis, concentrations between $75 \mathrm{mM}$ to $1 \mathrm{~nm}$ could not inhibit the bacteria. (Table 2)

\section{DISCUSSION}

Boric acid has previously been reported to have antibacterial effects on some oral bacteria including Staphylococcus aureus ${ }^{23}$, Streptococcus mutans and Enterococcus faecalis ${ }^{16}$. However no study has evaluated the effects of Boric acid on F. nucleatum and $P$. gingivalis. Determination of MIC and MBC of a potential therapeutic agent for use in disease management is essential to determine the sensitivity and/or resistance of bacteria and, also to monitor their efficacy. In the present study, the MIC values of boric acid determined for $P$. gingivalis and F. nucleatum were determined to be in the $\mu \mathrm{M}$ and $\mathrm{nM}$ range respectively, but the MBC value of $F$. nucleatum was notably higher ( $\mathrm{mM}$ range) and, finally no MBC could be determined for $P$. gingivalis within the tested concentration range.

Table 1: MIC of Boric Acid on F.nucleatum and P. gingivalis

\begin{tabular}{|c|c|c|c|c|c|c|c|c|c|c|c|c|c|}
\hline \multirow[t]{3}{*}{ Bacteria } & \multicolumn{13}{|c|}{ Concentration } \\
\hline & 800 & 400 & 200 & 100 & 50 & 25 & 12.5 & 6.25 & 3.12 & 1.56 & 780 & 390 & 195 \\
\hline & $\mu \mathrm{M}$ & $\mu \mathrm{M}$ & $\mu \mathrm{M}$ & $\mu \mathrm{M}$ & $\mu \mathrm{M}$ & $\mu \mathrm{M}$ & $\mu \mathrm{M}$ & $\mu \mathrm{M}$ & $\mu \mathrm{M}$ & $\mu \mathrm{M}$ & $\mathrm{nM}$ & $\mathrm{nM}$ & $\mathrm{nM}$ \\
\hline F. nucleatum & $\mathrm{S}$ & $\mathrm{S}$ & S & $\mathrm{S}$ & $\mathrm{S}$ & $\mathrm{S}$ & $\mathrm{S}$ & $\mathrm{S}$ & $\mathrm{S}$ & $\mathrm{S}$ & $\mathrm{S}$ & $\mathrm{R}$ & $\mathrm{R}$ \\
\hline P. gingivalis & $\mathrm{S}$ & $\mathrm{S}$ & $\mathrm{S}$ & S & $\mathrm{S}$ & $\mathrm{S}$ & $\mathrm{S}$ & $\mathrm{S}$ & $\mathrm{S}$ & $\mathrm{S}$ & $\mathrm{R}$ & $\mathrm{R}$ & $\mathrm{R}$ \\
\hline
\end{tabular}

S: Sensitive, R: Resistance

Table 2: MBC determination of Boric Acid on F.nucleatum and P. gingivalis

\begin{tabular}{cccccccc}
\hline \multicolumn{1}{c}{ Bacteria } & \multicolumn{7}{c}{ Concentration } \\
\hline & $\begin{array}{c}75 \\
\mathrm{mM}\end{array}$ & $\begin{array}{c}37.5 \\
\mathrm{mM}\end{array}$ & $\begin{array}{c}18.75 \\
\mathrm{mM}\end{array}$ & $\begin{array}{c}9.3 \\
\mathrm{mM}\end{array}$ & $\begin{array}{c}4.68 \\
\mathrm{mM}\end{array}$ & $\begin{array}{c}2.34 \\
\mathrm{mM}\end{array}$ \\
\hline F. nucleatum & $\mathrm{N}-\mathrm{G}$ & $\mathrm{N}-\mathrm{G}$ & $\mathrm{N}-\mathrm{G}$ & $\mathrm{G}$ & $\mathrm{G}$ & $\mathrm{G}$ & $\mathrm{G}$ \\
\hline P. gingivalis & $\mathrm{G}$ & $\mathrm{G}$ & $\mathrm{G}$ & $\mathrm{G}$ & $\mathrm{G}$ & $\mathrm{G}$ \\
\hline
\end{tabular}

N-G: Non-growth, G: Growth 
Previously boric acid has been reportedly used for the treatment of periodontal disease in human and animal studies ${ }^{12-16}$. Kanoriya et al. ${ }^{15}$ evaluated the efficiency of $0.75 \%$ subgingivally delivered boric acid in addition to conventional mechanical therapy and found that it significant improved periodontal disease parameters including probing depth and clinical attachment level and reduced the defect depth radiologically compared with the placebo group over a 6 month treatment period. Singhal et al. ${ }^{14}$ also investigated the same concentration of Boric acid gel in addition to conventional periodontal treatment in the treatment of class II furcation defects at 6 months and reported greater probing depth reduction and clinical attachment gain and also bone formation in the boric acid gel treatment group compared with the placebo group at 6 months. Saglam et al. ${ }^{16}$ also compared the effects of a $0.75 \%$ boric acid mouthwash with chlorhexidine on clinical parameters and bacterial counts for several periodontal pathogens including $P$. gingivalis, Tannerella forsythia, and Treponema denticola at 3 months in chronic periodontitis patients. They reported a significant reduction in bleeding on probing, probing pocket depth and clinical attachment level in moderate periodontal pockets (probing depth $\geq 5$ and $<7$ ) at the 1 month treatment period however no differences were found for bacterial counts in any time period up to 3 months. In the current study the maximum tested concentration was $(75 \mathrm{mM}=0.50 \%)$ lower than all of the three clinical studies reported above. The ability of Boric acid to reduce periodontal pathogen infection may be due to the bacteriostatic effects of the compound on $P$. gingivalis that was shown in the current study. However, the compound should also be tested on biofilms as it is known that this growth mode results in bacteria being more resistant to antimicrobial agents ${ }^{24}$. The previously mentioned studies also provided data on the toxicity of these boron containing compounds on gingival fibroblasts and periodontal ligament cells, reporting that $0.75 \%$ boric acid did not exhibit any adverse effects. However no data was reported regarding the cytotoxicity of the compounds on osteoblasts or keratinocytes and these are major cell types present in the oral cavity and relevant to periodontitis pathogenesis. Further studies should also be conducted to confirm the safe dose for this compound on these cell types as this would have clinical relevance.

In the literature in vivo studies have also evaluated the effects of boric acid as a dietary supplement for the treatment of experimental periodontitis in rats. Saglam et al. ${ }^{12}$ applied boric acid at $3 \mathrm{mg} / \mathrm{kg}$ daily for
11 days in rats with experimental periodontitis and they concluded that administration of boric acid may reduce alveolar bone loss by affecting the Receptor activator of nuclear factorkappa B ligand (RANKL)/Osteoprotegerin (OPG) ratio which is a good indicator of bone turnover in experimental periodontitis. Demirer et al. ${ }^{13}$ also evaluated the effects of the same dose of Boric acid over the same time period (3mg/kg administered daily for 11 days) on periodontal inflammation and osteoblast/ osteoclast number in rats with experimental periodontitis. They detected significant improvements for periodontal inflammation and bone formation in rats supplemented with boric acid. However the two studies ${ }^{12,}{ }^{13}$ did not report on any data for bacterial counts preventing any discussion about the compound's antimicrobial effects in experimental periodontitis.

In the literature the effects of boron compounds on microorganisms was also evaluated and Boron containing compounds were found to impair protein synthesis and the activity of certain enzymes including serine-protease, $\beta$-lactamase ${ }^{25}$. In the current study although we detected some inhibitory effects of boric acid on $P$. gingivalis and F. nucleatum the exact mechanism of action of the compound on the bacteria has not been elucidated and is the focus of future studies.

This is the first study to show the antimicrobial effects of boric acid on P. gingivalis and F. nucleatum. Therefore, boric acid may have potential to use as an antimicrobial agent including mouthwash and gel in the management of periodontal disease. In future, bone protective and antiinflammatory effects of boric acid will also be assessed in vitro that may also extend the use of boric acid in the field of periodontology.

\section{CONCLUSION}

Our findings established MICs of $780 \mathrm{nM}$ and 1.56 $\mu \mathrm{M}$ respectively of boric acid for both $F$. nucleatum and $P$.gingivalis. Therefore, boric acid has antimicrobial effects towards periodontal pathogens, that can make it a desirable antimicrobial agent in mouthwash or subgingival gel for periodontal disease management. Further work is required to evaluate the possible antiinflammatory potential and bone protective effects of boric acid on periodontal inflammation in vitro, which may widen the application of boric acid in periodontology. 


\section{REFERENCES}

1. Kinane DF, Lappin DF. Immune processes in periodontal disease: a review. Ann Periodontol 2002;7:62-71.

2. Schmidt J, Jentsch H, Stingu CS, Sack U. General immune status and oral microbiology in patients with different forms of periodontitis and healthy control subjects. PLoS One 2014;9:e109187.

3. Kolenbrander PE. Oral microbial communities: biofilms, interactions, and genetic systems. Annu Rev Microbiol 2000;54:413-437.

4. Slots J. Selection of antimicrobial agents in periodontal therapy. J Periodontal Res 2002;37:389398.

5. Heta S, Robo I. The Side Effects of the Most Commonly Used Group of Antibiotics in Periodontal Treatments. Med Sci (Basel) 2018;6.

6. Mombelli A, Samaranayake LP. Topical and systemic antibiotics in the management of periodontal diseases. Int Dent J 2004;54:3-14.

7. Mariotti AJ, Rumpf DA. Chlorhexidine-induced changes to human gingival fibroblast collagen and non-collagen protein production. J Periodontol 1999;70:1443-1448.

8. WalkerCB,KarpiniaK,BaehniP.Chemotherapeutics: antibiotics and other antimicrobials. Periodontol 2000 2004;36:146-165.

9. Benderdour M, Bui-Van T, Dicko A, Belleville F. In vivo and in vitro effects of boron and boronated compounds. J Trace Elem Med Biol 1998;12:2-7.

10. Gorustovich AA, Steimetz T, Nielsen FH, Guglielmotti MB. Histomorphometric study of alveolar bone healing in rats fed a boron-deficient diet. Anat Rec (Hoboken) 2008;291:441-447.

11. Yang F, Zhu M, Zhang J, Zhou H. Synthesis of biologically active boron-containing compounds. Medchemcomm 2018;9:201-211.

12. Saglam M, Hatipoglu M, Koseoglu S, Esen HH, Kelebek S. Boric acid inhibits alveolar bone loss in rats by affecting RANKL and osteoprotegerin expression. J Periodontal Res 2014;49:472-479.
13. Demirer S, Kara MI, Erciyas K, Ozdemir H, Ozer $\mathrm{H}$, Ay S. Effects of boric acid on experimental periodontitis and alveolar bone loss in rats. Arch Oral Biol 2012;57:60-65.

14. Singhal S, Pradeep AR, Kanoriya D, Garg S, Garg V. Boric acid gel as local drug delivery in the treatment of class II furcation defects in chronic periodontitis: a randomized, controlled clinical trial. J Investig Clin Dent 2018;9.

15. Kanoriya D, Singhal S, Garg V, Pradeep AR, Garg S, Kumar A. Clinical efficacy of subgingivallydelivered $0.75 \%$ boric acid gel as an adjunct to mechanotherapy in chronic periodontitis: A randomized, controlled clinical trial. J Investig Clin Dent 2018;9.

16. Saglam M, Arslan U, Buket Bozkurt S, Hakki SS. Boric acid irrigation as an adjunct to mechanical periodontal therapy in patients with chronic periodontitis: a randomized clinical trial. $J$ Periodontol 2013;84:1297-1308.

17. Tepedelen BE, Soya E, Korkmaz M. Boric Acid Reduces the Formation of DNA Double Strand Breaks and Accelerates Wound Healing Process. Biol Trace Elem Res 2016;174:309-318.

18. Hirschfeld J, White PC, Milward MR, Cooper PR, Chapple ILC. Modulation of Neutrophil Extracellular Trap and Reactive Oxygen Species Release by Periodontal Bacteria. Infect Immun 2017;85.

19. Wei GX, Campagna AN, Bobek LA. Effect of MUC7 peptides on the growth of bacteria and on Streptococcus mutans biofilm. J Antimicrob Chemother 2006;57:1100-1109.

20. European Committee for Antimicrobial Susceptibility Testing (EUCAST) of the European Society of Clinical Microbiology and Infectious Diseases (ESCMID). Determination of minimum inhibitory concentrations (MICs) of antibacterial agents by broth dilution. Clinical Microbiology and Infection 2003;9:1-7.

21. Rotilie CA, Fass RJ, Prior RB, Perkins RL. Microdilution technique for antimicrobial susceptibility testing of anaerobic bacteria. Antimicrob Agents Chemother 1975;7:311-315. 
22. Leandro LF, Moraes Tda S, de Oliveira PF, et al. Assessment of the antibacterial, cytotoxic and mutagenic potential of the phenolic-rich hydroalcoholic extract from Copaifera trapezifolia Hayne leaves. J Med Microbiol 2016;65:937-950.

23. Sayin Z, Ucan US, Sakmanoglu A. Antibacterial and Antibiofilm Effects of Boron on Different Bacteria. Biol Trace Elem Res 2016;173:241-246.

24. Adriztina I, Adenin LI, Lubis YM. Efficacy of Boric Acid as a Treatment of Choice for Chronic Suppurative Otitis Media and Its Ototoxicity. Korean J Fam Med 2018;39:2-9.

25. Yilmaz MT. Minimum inhibitory and minimum bactericidal concentrations of boron compounds against several bacterial strains. Turk J Med Sci 2012;42:1423-1429. 